\title{
Phytochemical screening, Mineral and Amino acids Compositions of Carica papaya root in South western Nigeria
}

\author{
Ayoola, P.B. (Corresponding author) \\ Department of Science Laboratory Technology, Ladoke Akintola University of Technology, \\ P.M.B. 4000, Ogbomoso, Oyo State, Nigeria. \\ E-mail: pbayoola@yahoo.com \\ Ibikunle, G.J. \\ Department of Science Laboratory Technology, Ladoke Akintola University of Technology, \\ P.M.B. 4000, Ogbomoso, Oyo State, Nigeria. \\ Oyewande, E.A. \\ Department of Science Laboratory Technology, Ladoke Akintola University of Technology, \\ P.M.B. 4000, Ogbomoso, Oyo State, Nigeria. \\ Odeniyi, M.A. \\ Department of Science Laboratory Technology, Ladoke Akintola University of Technology, \\ P.M.B. 4000, Ogbomoso, Oyo State, Nigeria. \\ Akintola, A.O. (Corresponding author) \\ Department of Science Laboratory Technology, Ladoke Akintola University of Technology, \\ P.M.B. 4000, Ogbomoso, Oyo State, Nigeria. \\ E-mail: aoakintola@lautech.edu.ng
}

\begin{abstract}
Sample of Carica papaya root was collected from the teaching and research farm of Faculty of Agricultural Sciences, Ladoke Akintola University of Technology, Ogbomoso, Oyo State, Nigeria and analyzed for phytochemical, mineral and amino acids constituents of the root, using standard methods of analysis.

Phytochemical screening revealed the presence of secondary metabolites such as alkaloids, saponin, tannin, steroid, cardiac glycosides, anthraquinone, and cardiac glycoside while flavonoid was absent. The result of mineral analysis showed the amount of mineral present in the following order: $\mathrm{K}>\mathrm{Mg}>\mathrm{Na}>\mathrm{Fe}>\mathrm{Ca}>\mathrm{Mn}>\mathrm{Zn}$. Amino acids analysis revealed that glycine $(0.15 \pm 0.002)$ was the highest amount present in the root followed by phenylalanine $(0.100 \pm 0.001)$, isoleucine $(0.087 \pm 0.000)$, leucine $(0.085 \pm 0.000)$, histidine $(0.066 \pm 0.000)$, lysine $(0.054 \pm 0.003)$, trypsin $(0.044 \pm 0.003)$, threonine $(0.044 \pm 0.001)$ and valine $(0.043 \pm 0.000)$ while others were present in traces.

The presence of secondary metabolites, essential minerals and amino acids in the root could make the root possess medicinal properties which could be used in the prophylactic and therapeutic control of ailments.

Therefore, the root could be manipulated in the herbal treatment of various diseases and as a potential source of useful elements for drugs formulation.
\end{abstract}

Keywords: papaya, minerals, phytochemicals, prophylactic, therapeutic

DOI: $10.7176 / J S T R / 6-09-04$

\section{Introduction}

Carica papaya Linnaeus, belongs to the family of Caricaceae. It is known in South western Nigeria as "Ibepe". Carica papaya is an herbaceous succulent plant which possesses self supporting stems not a tree that possesses hard stem or trunk (Dick Gross, 2003). The C. papaya plants are usually short-lived, but can produce fruit for many years if not cut down or destroyed. It has a complicated means of 
reproduction and grows in three sexes: male, female and hermaphrodite (Bruce and Peter, 2008). The male plants are uncommon; they produce only pollen, no fruit. The female produces small inedible fruits unless it is pollinated before a well developed and bulky fruits are produced. The hermaphrodite plants (flowers with male and female parts) are the commercial type, this can self- pollinate because its flowers contain both male stamens and female ovaries (Jari,2009). Carica papaya plants produce natural compounds (annonaceous acetogenins) in leaf, bark and twig tissues that possess both highly anti-tumour and pesticidal properties. It was suggested that a potentially lucrative industry based simply on production of plant biomass could develop for production of anti-cancer drugs, pending Food and Drug Agency approval, and natural (botanical) pesticides (Mc Langhlin, 1992).

The high level of natural self-defence compounds in the plant makes it highly resistant to insect and disease infestation (Peter, 1991). The papaya fruit, stem, leaves and the root contain a milky juice in which papain is present. Apart from its value as a remedy in dyspepsia and other ailments, it has also been utilized for the clarification of beer. It has been reported that the juice has been used on meat to make it tender (Wilson, 1974). The seed has also been reported to be effective when chewed for intestinal worms. The root is chewed and the juice swallowed for cough, bronchitis, and other respiratory diseases. The unripe fruit is used as a remedy for ulcer and impotence (Elizabeth, 1994). Fresh, green pawpaw leaf is an antiseptic, whilst the brown, dried pawpaw leaf is the best as a tonic and blood purifier (Atta, 1999). Juice from Carica papaya root is used in some Asia countries to ease urinary troubles and a decoction formed by boiling the outer part of the root is used to treat dyspepsia (Arvind et al., 2013). When the seeds of ripe Carica papaya are chewed they help to clear nasal congestion (Elizabeth, 1994). The green unripe fruit has a healing property due to its antiseptic quality, therefore, it is able to clean intestines from bacteria, however, it is only a healthy intestine that can absorbs vitamin and minerals, especially vitamin $\mathrm{B}_{12}$. The tea, prepared with the green papaya leaf, promotes digestion and aids the treatment of ailments such as chronic indigestion, overweight and obesity, arteriosclerosis, high blood pressure and weakening of the heart (Mantok, 2005). Some benefits of papaya root and their preparations are as follow; the root is use for deworming, preparation: Weigh $10 \mathrm{~g}$ of dried papaya root, $1 \mathrm{~g}$ of garlic, and $100 \mathrm{ml}$ of water. Cut everything into pieces, boil with water for $15 \mathrm{~min}$ and then filtered. If necessary, add boiled water to obtain filtrate of $75 \mathrm{ml}$. The root could also be use as beverages: take two pieces of papaya roots and leaves. The leaf is finely ground, boil with one litre of water until boiling and then strain. If necessary, mix honey or fresh ginger to taste. The root could also be used as preventive measure for kidney stones: take three pieces of papaya roots, then boiled with one litre of water until boiling, then strain. Once, cool mix with a little honey, then drink. It is used for bladder pain and snake poison: Weigh $10 \mathrm{~g}$ of the papaya root and $10 \mathrm{~g}$ of dried garlic. Simmer the mixture in $100 \mathrm{ml}$ of water for $15 \mathrm{~min}$, then filtered, if necessary, add boiled water to $75 \mathrm{ml}$ of the filtrate obtained, taken three times a day (each 25 $\mathrm{ml}$ ). The root could be use to prevent the risk of kidney stones and kidney inflammation and the preparation is as follows; weigh $30 \mathrm{~g}$ of papaya roots, boiled with $800 \mathrm{ml}$ of water until the remaining $450 \mathrm{ml}$, then strain, Once cool, mix with a little honey, then drink ( 3 times a day each $150 \mathrm{ml}$ ). Alternatively, weigh $30 \mathrm{~g}$ of papaya root, $15 \mathrm{~g}$ of fresh cat whiskers plant and $30 \mathrm{~g}$ roots of the weeds. Boiled with $800 \mathrm{ml}$ of water until the remaining $400 \mathrm{ml}$, then filtered, drink 2 times a day (each 200ml). For urinary tract disorders; take 3 pieces of papaya roots, boiled with 1 litre of water until boiling, then strain, drink $1 / 2$ cup once a day. Application of the root in the treatment of rheumatism has also been claimed and this is the local preparation of the medicament; blend $30 \mathrm{~g}$ of papaya root, $20 \mathrm{~g}$ of lime leaves, $15 \mathrm{~g}$ of fresh bitter leaves, 20g ketepeng cina (Cassia alata), 30g of fresh betel leaf (Asian or climbing pepper) and 5 pieces of cayenne pepper. Soak in a mixture of $75 \%$ alcohol for 7 days, then squeeze and strain. Use water to rub and massage the affected part. Do it 2-3 times a day (Arlina, 2015). The objective of this study is to determine the phytochemical, mineral and amino acids constituents of Carica papaya root as a basis for local treatment and prevention of some diseases and also could serve as raw materials in local herbal drug production.

\section{Materials and Methods}

\section{Source of plant materials}

The Carica papaya root was uprooted from the teaching and research farm of Faculty of Agricultural Sciences, Ladoke Akintola University of Technology, Ogbomoso, Oyo State, Nigeria.

\section{Sample preparation}

The root was washed with distilled water, cut into small pieces with the aid of a stainless knife and sun dried for fifteen days. The sample was ground into powder and stored in an air tight bottle prior to analysis. 
Phytochemical screening of the root.

The analysis for tannin (determined using the Braymer's test), saponins (determined using foam test), cardiac glycosides (Keller-Killani test) and alkaloids (Harborne method) were carried out according to standard methods (Sofowora, 1993).

\section{Mineral analysis}

Minerals were determined by digesting the ash with 3M Hydrochloric acid and the filtrate measured using the atomic absorption spectrophotometer for iron ( $\mathrm{Fe})$, manganese $(\mathrm{Mn})$, zinc $(\mathrm{Zn})$, cadmium $(\mathrm{Cd})$, and flame photometer for calcium $(\mathrm{Ca})$, magnesium $(\mathrm{Mg})$, potassium $(\mathrm{K})$ and sodium $(\mathrm{Na})$ (Pearson, 1981).

\section{Amino Acids analysis}

The free amino acids concentrations were determined with ninhydrin reagent using phenylalanine as standard and reading the developed color at $570 \mathrm{~nm}$ and extrapolating the values from a standard curve of phenylalanine. Ninhydrin in acetone $(0.1 \%)$ was diluted with distilled water in the ratio 1:4. Exactly, $20 \mu \mathrm{L}$ each of the diluted extracts was added to $4 \mathrm{ml}$ portions of the diluted ninhydrin. The resulting solutions were heated to boiling for $5 \mathrm{~min}$, cooled and the absorbance read in a spectrophotometer at 570nm using distilled water as blank (Schroeder et al., 1990; Edem et al., 1990). The major amino acids constituents of the samples were carried out with the aid of Technicon Sequential Multi sample Amino acid Analyzer (TSM) (Yemm and Cooking, 1954).

\section{Results and Discussion}

The Phytochemical screening of the root (Table 1) showed that the root contained saponins, cardiac glycosides, alkaloids and tannin while flavonoid was absent. The presence of saponins supports the fact that the Carica papaya root could have cytotoxic effects and have relationship with sex hormones like oxytocin. Oxytocin is a sex hormone involved in controlling the onset of labour in women and the subsequent release of milk (Okwu and Okwu, 2004). Another important action of saponins is their expectorant action through the stimulation of a reflex of the upper digestive tract (David, 1983). Alkaloids are the most efficient therapeutic compounds used medicinally because of their analgesic, antispasmodic and bacterial properties (Stray, 1998). The cardiac glycosides have the ability to increase the force and power of the heart-beat without increasing the amount of oxygen needed by the heart muscle. They can thus increase the efficiency of the heart and at the same time steady excess heart beats without strain to the organ (David, 1983). In table 2, the result of the mineral composition clearly showed that Carica papaya root is a rich source of mineral elements. The presence of calcium and magnesium is an indication that the root could be useful in bone formation and management and use for the prevention and treatment of bone related ailments. Magnesium, assist in the assimilation of phosphorus. Lack of magnesium can be responsible for tetany, tuberculosis, diabetes, cancer and all nervous diseases (Claude and Paule, 1979). Potassium is necessary for muscular weakness which is associated with malaria, and also slows down sclerosis of the vascular system. It contributes to the fight against bacteria and cleanses the digestive system. Sodium is involved in the metabolism of water, promotes digestion, assimilation, osmosis, cleanses the digestive system, combats stomach acidity and alkalizes the blood (Claude and Paule, 1979). The presence of Iron in the root indicates that it could be used against any ailment involving disorderliness in the blood function such as anaemia, tuberculosis and disorder of growth. (Claude and Paule, 1979). Iron is an energizer but excess can cause fatigue but we hardly have excess if taken from natural source (Gbolahan, 2001).

Manganese, according to Claude and Paule (1979) is necessary for the functioning of the pituitary gland, the pineal gland and the brain. It promotes hepato-renal function, combat anaemia and it is also essential for growth. The presence of zinc is an indication that Carica papaya root has some effect on the nerve function and male fertility. It is important for normal sexual development, especially for the development of testes and ovaries, it is also essential for reproduction. Zinc stimulates the activity of vitamins, formation of red and white corpuscle, healthy functioning of the heart and normal growth. The root of Carica papaya is a good source of essential amino acids such as; isoleucine, leucine, phenylalanine, histidine, lysine and valine, and non essential amino acids such as, glycine (which was abundant in the root), glutanic, aspartic acid, proline and cysteine (Table 3). Phenylalanine promotes alertness and vitality, elevates mood, decreases pain, aids memory and learning, used to treat arthritis, depression, menstrual cramps, migraine obesity, Parkinson's diseases and schizophrenia. Isoleucine aids in the healing, repair of muscle tissue, skin, and bone and needed for haemoglobin formation, stabilizing, regulating blood sugar and energy (Elizabeth, 1994). Leucine promotes the healing of muscle tissue, skin and bones. Leucine is recommended for those recovering from surgery, lower blood sugar level and aids

23 | P a g e 
in increasing growth hormone. Deficiency in the essential amino acids may hinder healing recovery process (Egan and Sawyer, 1981). Histidine aids in sexual arousal, removal of heavy metals from the body, lower blood pressure and protect body from radiation damage.

Table 1: Phytochemical Screening of the Carica papaya root

\begin{tabular}{|c|c|}
\hline Constituent & Bioassay \\
\hline Alkaloid & + \\
\hline Flavonoid & - \\
\hline Saponin & + \\
\hline Tannin & + \\
\hline Steroid & + \\
\hline Cardiac glycosides & + \\
\hline Anthraquinone & + \\
\hline
\end{tabular}

Results are means of three determinations.

$$
+=\text { presents. } \quad-=\text { No activity }
$$

Table 2: Mineral Compositions of the Carica papaya on dry weight basis $(\mu \mathrm{g} / \mathrm{g})$

\begin{tabular}{|c|c|}
\hline Mineral & Composition $(\boldsymbol{\mu g} / \mathbf{g})$ \\
\hline Calcium $(\mathrm{Ca})$ & $129.55 \pm 0.12$ \\
\hline Magnesium $(\mathrm{Mg})$ & $2934.70 \pm 0.05$ \\
\hline Potassium $(\mathrm{K})$ & $21592.50 \pm 0.02$ \\
\hline Sodium $(\mathrm{Na})$ & $2827.50 \pm 0.05$ \\
\hline Copper $(\mathrm{Cu})$ & $5.550 \pm 0.01$ \\
\hline Iron $(\mathrm{Fe})$ & $333.20 \pm 0.05$ \\
\hline Manganese $(\mathrm{Mn})$ & $73.900 \pm 0.02$ \\
\hline Zinc $(\mathrm{Zn})$ & $35.45 \pm 0.01$ \\
\hline Cadmium $(\mathrm{Cd})$ & $4.200 \pm 0.02$ \\
\hline Lead $(\mathrm{Pb})$ & $\mathrm{ND}$ \\
\hline
\end{tabular}

Results are means of three determinations \pm SD

$$
\mathrm{ND}=\text { Not Detected }
$$

Table 3: Amino acids compositions of Carica papaya root

\begin{tabular}{|c|c|}
\hline Amino acid & Composition (\%) \\
\hline Methionine & $0.020 \pm 0.001$ \\
\hline Valine & $0.043 \pm 0.000$ \\
\hline Lysine & $0.054 \pm 0.003$ \\
\hline Isoleucine & $0.087 \pm 0.000$ \\
\hline Phenylalanine & $0.100 \pm 0.001$ \\
\hline Threonine & $0.044 \pm 0.001$ \\
\hline Leucine & $0.085 \pm 0.000$ \\
\hline Histidine & $0.066 \pm 0.000$ \\
\hline Cysteine & $0.016 \pm 0.000$ \\
\hline Trypsin & $0.044 \pm 0.003$ \\
\hline Glycine & $0.153 \pm 0.002$ \\
\hline Glutamic & $0.032 \pm 0.002$ \\
\hline Aspartic acid & $0.006 \pm 0.000$ \\
\hline
\end{tabular}

Results are means of three determinations $\pm \mathrm{SD}$

Lysine aids calcium absorption and maintain a proper nitrogen balance in adults. Also aids in the production of antibodies which have the ability to fight cold sores and herpes outbreaks, helps form collagen, which makes up cartilage and connective tissue. Valine aids muscle metabolism and coordination, tissue repair and for the maintenance of proper nitrogen balance in the body. It is used as an energy source by muscle tissue, helpful in treating liver and gall bladder disease (Jari, 2009). Threonine helps maintain proper protein balance in the body, important for the formation of collagen, elastin and tooth enamel, aids liver and lipotropic function when combined with aspartic acid and methionine, prevents the build up of fat in the liver. Cysteine is an antioxidant, it protects the body from radiation damage, protects the liver and brain from damage due to alcohol, drugs and toxic compounds 
found in cigarette smoke. It is used in the treatment of rheumatoid arthritis and hardening of the arteries. Promotes the recovery from severe burns and surgery, promotes the burning of fat and the building of muscle. Slow down aging process. Glycine retards muscle degeneration, improves glycogen storage thus freeing up glucose for energy needs, promotes a healthy prostrate, central nervous system and immune system, useful for repairing damaged tissue and promotes healing (Desmond, 1995; Njoku and Akumefula, 2007). Proline improves skin texture by aiding the production of collagen and reducing the loss of collagen through the aging process, helps in the healing of cartilage and the strengthening of joints, tendons and heart muscles, works with vitamin $\mathrm{C}$ to promote healthy connective tissues (David, 1983).

\section{Conclusion}

This study showed that the root of Carica papaya has everything it takes to be effective in the claimed efficacy of the root in the treatment and prevention of some disorderliness in human beings. Therefore, this plant should be nurtured, preserved and utilized as one of the medicinal plants that could generate revenue for the country and pharmaceutical industries should take advantage of these properties in the formulation of drug production.

\section{REFERENCES.}

[1] Atta, K. Bonsu (1999)." The Power of Garlic". Cardiovascular disease prevention Association, Buea, Cameroon. p.72.

[2] Arlina, D., (2015). The benefits of Vegetables and Fruits. Google Facebook Twitter

[3] Arvind, G., Bhowmik, D., Duraivel, S, and Harish, G., (2013). Traditional and medicinal uses of Carica papaya. J. Med. Car Pap: 1(1): 2320-3862

[4] Bruce, S. and Peter, C. A. (2008). Handbook of environmental physiology of fruit crops. $1^{\text {st }}$ Ed. p.217.

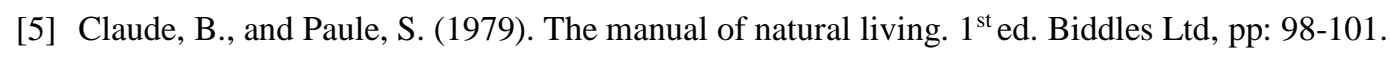

[6] David, H. (1983). The new holistic herbal. $3^{\text {rd }}$ Ed. Findhorn press, U.S.A. p: 241.

[7] Desmond, R. Layne (1995)". Pawpaw": New crop factsheet. Department of Horticulture, Poole Agriculture Centre, Clemson University, Clemson, Sc. 29634-0375.

[8] Dick Gross (2003). "Papaya": A tantalising taste of the Tropics. Maricopa County Master Gardener Volunteer information, University of Arizona Cooperative Extension. www.papaya Maricopahort@ag.arizo.edu.

[9] Edem, D.O., Amugo, C.I., and Eka, O.U (1990). Chemical composition of yam beans (Sphenostylis stenocarpa). Trop. Sci. 30:59-63

[10] Egan, H., Kirk, R.S., and Sawyer, R., (1981). Pearson chemical analysis of foods. $8^{\text {th }}$ Ed. Churchill Livingstone, N. Y.

[11]Elizabeth Kafaru, (1994). Immense help from natures workshop. $1^{\text {st }}$ Ed. Elikaf Health Services Ltd. Ikeja, Lagos. Pp: 207-209.

[12] Gbolahan, D. (2001). Lesson note on medical importance of trace elements. Centre for Natural Health Studies, Surulere, Lagos, Nigeria.

[13] Jari, S. (2009). Papayas are yummy easy to grow. University of Hawaii- Manoa College of Tropical Agric. \& Human Resources.

[14] Mantok, C., (2005). Multiple usage of green papaya in healing at tao garden. Tao Garden Health spa and Resort. Thailand, www.tao-garden.com 
[15] McLanghlin, J. L., Ratanyake, S. Rupprecht, J. K. and, Potter, W. M. (1992). Evaluation of various parts of the pawpaw tree, Asimina triloba (Annonaceae), as commercial source of the pesticidal annonaceous acetogenins. J. Econ. Entomol. 85: 2353-2356.

[16] Njoku, P. C., and Akumefula M. I., (2007). Phytochemical and nutrient evaluation of Spondias mombin leaves. Pak. J. Nutr. 6(6): 613-615.

[17] Okwu, D. E, and Okwu, M.E., (2004). Chemical composition of Spondia mombin plants. J. Sustain Agric. Environ. 6: 140-147.

[18] Pearson, (1981). The chemical analysis of food, $8^{\text {th }}$ ed. London church hill Livingstone, 10: 9-12

[19] Peter, R. N. (1991). Pawpaw (Asimina). In: J. N. Moore and J. R. Ballington (eds). Genetic resources of temperate fruit and nut trees. Acta Hort. 290:567-600.

[20] Schroeder, W.A., Kay, L.M., and Mills, R.S. (1990). Standard spectrometric reading of amino acids. Analytical Chemistry. 22:760

[21] Sofowora, A. O., (1993). Medicinal plants and traditional medicine in Africa, Spectrum Books, University of Ife Press, Osun State, Nigeria. $2^{\text {nd }}$ Ed. Pp: 320.

[22] Stray, F., (1998). The natural guide to medicinal herbs and plants. Tiger Books International, London. Pp: 12-16.

[23] Wilson Popenoe, (1974). "Papaya"- Manual of tropical and subtropical fruits. Hafner Press. Facsimile of the 1920 Ed. Pp: 225-240.

[24] Yemm, E.W and Cooking, E.C (1954). The determination of amino acids with Ninhydrin. Analyst. 80: $209-213$ 